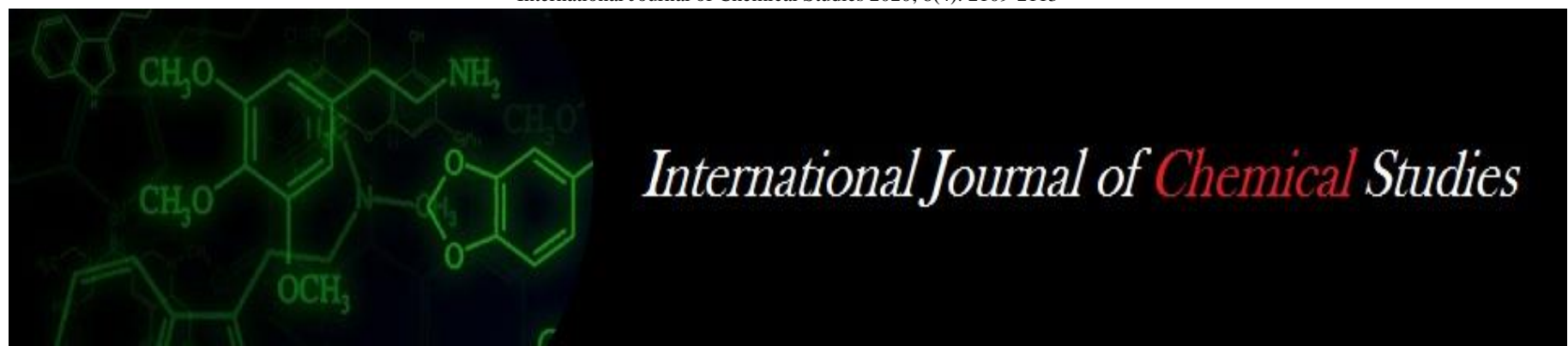

P-ISSN: 2349-8528

E-ISSN: 2321-4902

www.chemijournal.com

IJCS 2020; 8(4): 2109-2113

(C) 2020 IJCS

Received: 08-05-2020

Accepted: 10-06-2020

\section{Anilkumar AH}

Professor (Agronomy), Fodder

Research and Production

Scheme University of

Agricultural Sciences, Dharwad

Karnataka, India

\section{Kubsad VS}

Professor (Agronomy), Fodder

Research and Production

Scheme University of

Agricultural Sciences, Dharwad

Karnataka, India
Corresponding Author:

Kubsad VS

Professor (Agronomy), Fodder

Research and Production

Scheme University of

Agricultural Sciences, Dharwad

Karnataka, India

\section{Studies on nutrient uptake by rabi sorghum [Sorghum bicolor (L.) Moench] as influenced by fortified organics with iron and zinc}

\author{
Anilkumar AH and Kubsad VS
}

DOI: https://doi.org/10.22271/chemi.2020.v8.i4w.9938

\begin{abstract}
A field experiment was conducted during rabi 2016 under rainfed condition on clay loam soil at All India Coordinated Sorghum Improvement Project, Main Agricultural Research Station, Dharwad (Karnataka). The experiment was conducted to study the effect of fortification of organics with iron and zinc in rabi sorghum under rainfed condition. The experiment was laid out in randomized complete block design with three replications and eleven treatments. Results of the study revealed that soil application of RDF + Enriched FYM 1 recorded significantly higher nitrogen uptake $(57.19$ and $42.03 \mathrm{~kg} / \mathrm{ha}$ ), phosphorous uptake (23.13 and $24.14 \mathrm{~kg} / \mathrm{ha})$, potassium uptake (20.08 and $44.96 \mathrm{~kg} / \mathrm{ha})$, sulphur uptake (11.14 and $10.55 \mathrm{~kg} / \mathrm{ha})$, iron uptake (161.16 and $305.66 \mathrm{~g} / \mathrm{ha}$ ) and zinc uptake (116.27 and $213.21 \mathrm{~g} / \mathrm{ha})$ by grain and fodder respectively over control, recommended dose of fertilizer and recommended package of practice. Whereas, soil application of RDF + Enriched vermicompost 4 recorded significantly higher iron and zinc content both in grain (39.52 and $28.44 \mathrm{mg} / \mathrm{kg}$ ) and fodder (42.34 and $29.44 \mathrm{mg} / \mathrm{kg}$ ) respectively.
\end{abstract}

Keywords: Fortification, iron, rabi sorghum, uptake, zinc

\section{Introduction}

Plants require 16 nutrients (primary, secondary and micronutrients) for their normal growth and development. Micronutrients play a vital role in the growth and development of both crops and humans. These micronutrients are necessary for the plants to complete their life cycle (Chaney et al., 1992) ${ }^{[5]}$. Insufficient micronutrient availability in soils not only causes low crop productivity, but also poor nutritional quality of the crops and consequently contributes to malnutrition in the human population (Kumssa et al., 2015) ${ }^{[7]}$.

Zinc and iron deficiencies are a growing public health concern and socioeconomic issue, particularly in the developing countries (Welch and Graham 2004) ${ }^{[18]}$. Nearly five lakhs children under five years of age die annually due to zinc and iron deficiencies (Black et al., 2008) ${ }^{[2]}$. In Asia about 35 per cent of children between age group of 0 and 5 years suffer from zinc or iron deficiencies and 58 per cent of pregnant women in developing countries are anemic due to iron deficiency (Cababallero, 2002) ${ }^{[3]}$. Sorghum is the second cheapest source of energy and micronutrients after pearl millet and a majority of the population in central India depends on sorghum for their dietary energy and micronutrients requirement (Rao et al., 2006) [14]. The intake of iron and zinc in low income rural households in sorghum consuming regions is lower than the recommended dietary allowance. Fortification of sorghum by increasing mineral micronutrients (especially iron and zinc) in the grains provides a sustainable solution to iron and zinc deficiency (Pfeiffer and McClafferty, 2007) ${ }^{[13]}$. Rabi sorghum predominantly grown for food purposes had lower zinc and iron content than that of rainy season sorghums (Kumar et al., 2013) ${ }^{[6]}$. Most of the sorghum growing soils of arid and semi-arid regions of India are deficient in zinc and iron contents (Singh, 2001) ${ }^{[16]}$.

Hence, fortification in post-rainy sorghum cultivars is one of the cheapest options to address the problem of hidden hunger in predominantly sorghum consuming populations of semi-arid tropics. Addition of zinc enriched fertilizer to the soil results in increased uptake of zinc in wheat crop and increases the bio-available zinc concentration in the edible portion of the plant (Cakmak, 2008) ${ }^{[4]}$. Generally, farmers do not apply the recommended dose of fertilizer to rabi sorghum. They apply either urea or DAP or complex fertilizer which contain major nutrients ignoring the micronutrients (iron and zinc). 
Thus it leads to removal of micronutrients from soil resulting in nutrient deficiency over years. Hence the iron and zinc content in grain and fodder of rabi sorghum will be low. Rabi sorghum is mainly grown on vertisols, which are said to be calcareous in nature and these calcareous soils are deliberately found deficient in zinc and iron. Hence crop gown on these soils contains very low amount of zinc and iron due to lower uptake. In view of the above, a field experiment was conducted to study the uptake of nutrients by rabi sorghum as influenced by fortified organics with iron and zinc under rainfed condition.

\section{Materials and methods}

The field experiment was conducted during rabi 2016 under rainfed condition at All India Coordinated Sorghum Improvement Project, Main Agricultural Research Station, Dharwad (Karnataka) which is situated at $15^{\circ} 29^{\prime} \mathrm{N}$ latitude, $74^{0} 59^{\prime}$ E longitude at an altitude of $689 \mathrm{~m}$ above mean sea level and it comes under Northern transition zone (Zone-8) of Karnataka. The soil was clay loam, medium in organic carbon $(0.59 \%)$, low in available nitrogen $(245 \mathrm{~kg} / \mathrm{ha})$, medium in available phosphorous (22.64 kg/ha), high in available potassium (357.36 kg/ha), medium in available sulphur (19.80 $\mathrm{kg} / \mathrm{ha})$, deficient in iron $(4.24 \mathrm{mg} / \mathrm{kg})$ and zinc $(0.54 \mathrm{mg} / \mathrm{kg})$ and calcareous in nature $\left(8.05 \%\right.$ free $\mathrm{CaCO}_{3}$ content) with $\mathrm{pH}$ 7.45. The experiment was laid out in Randomized complete block design with three replications and eleven treatments. The treatments comprised of $\mathrm{T}_{1^{-}}$Control (no nutrients), $\mathrm{T}_{2^{-}}$ Recommended dose of fertilizer @ 50:25 kg N and $\mathrm{P}_{2} \mathrm{O}_{5} / \mathrm{ha}$ (RDF), $\mathrm{T}_{3}$ - Recommended package of practice includes RDF+ $15 \mathrm{~kg} \mathrm{ZnSO} / \mathrm{ha}$ and seed treatment with Azospirillum @ 500 g/ha (RPP), T 4 - RDF+ Enriched FYM 1 [(50 kg FYM/ha + $3.75 \mathrm{~kg} \mathrm{ZnSO} / \mathrm{ha})+(50 \mathrm{~kg} \mathrm{FYM} / \mathrm{ha}+3.75 \mathrm{~kg} \mathrm{FeSO} / \mathrm{ha})]$, $\mathrm{T}_{5^{-}} \mathrm{RDF}+$ Enriched FYM $2[(50 \mathrm{~kg} \mathrm{FYM} / \mathrm{ha}+7.5 \mathrm{~kg}$ $\left.\left.\mathrm{ZnSO}_{4} / \mathrm{ha}\right)+(50 \mathrm{~kg} \mathrm{FYM} / \mathrm{ha}+7.5 \mathrm{~kg} \mathrm{FeSO} / \mathrm{ha})\right], \mathrm{T}_{6}-\mathrm{RDF}+$ Enriched FYM 3 [(50 kg FYM/ha + $11.25 \mathrm{~kg} \mathrm{ZnSO} 4 / \mathrm{ha}]+$ $[50 \mathrm{~kg} \mathrm{FYM} / \mathrm{ha}+11.25 \mathrm{~kg} \mathrm{FeSO} / \mathrm{ha})], \mathrm{T}_{7}-\mathrm{RDF}+$ Enriched FYM 4 [(50 kg FYM/ha + 15 kg ZnSO $/$ ha $)+(50 \mathrm{~kg} \mathrm{FYM/ha}$ $+15 \mathrm{~kg} \mathrm{FeSO} / \mathrm{ha})], \mathrm{T}_{8}-\mathrm{RDF}+$ Enriched vermicompost 1 [(50 kg vermicompost/ha + $\left.3.75 \mathrm{~kg} \mathrm{ZnSO}_{4} / \mathrm{ha}\right)+(50 \mathrm{~kg}$ vermicompost $\left.\left./ \mathrm{ha}+3.75 \mathrm{~kg} \mathrm{FeSO}_{4} / \mathrm{ha}\right)\right], \mathrm{T}_{9}-\mathrm{RDF}+$ Enriched vermicompost 2 [(50 kg vermicompost $/ \mathrm{ha}+7.5 \mathrm{~kg} \mathrm{ZnSO} / 4 / \mathrm{ha})$ + (50 kg vermicompost/ha + $7.5 \mathrm{~kg} \mathrm{FeSO} / \mathrm{ha})], \mathrm{T}_{10}-\mathrm{RDF}+$ Enriched vermicompost 3 [(50 kg vermicompost/ha +11.25 $\mathrm{kg} \mathrm{ZnSO} / \mathrm{ha})+(50 \mathrm{~kg}$ vermicompost $/ \mathrm{ha}+11.25 \mathrm{~kg}$ $\left.\left.\mathrm{FeSO}_{4} / \mathrm{ha}\right)\right]$ and $\mathrm{T}_{11}-\mathrm{RDF}+$ Enriched vermicompost $4[(50 \mathrm{~kg}$ vermicompost/ha $\left.+15 \mathrm{~kg} \mathrm{ZnSO}_{4} / \mathrm{ha}\right)+(50 \mathrm{~kg}$ vermicompost/ha $\left.\left.+15 \mathrm{~kg} \mathrm{FeSO}_{4} / \mathrm{ha}\right)\right]$.

\section{Enrichment method}

FYM and vermicompost @ $50 \mathrm{~kg} / \mathrm{ha}$ each were mixed with different quantities of $\mathrm{ZnSO}_{4}$ as per the treatments $(3.75,7.5$, 11.25 and $15 \mathrm{~kg} / \mathrm{ha}$ ) separately. Little quantity of water was added to the mixture at field capacity and the mixture was kept in polythene bags under anaerobic condition for 15 days for incubation. The moisture content in the mixture was checked weekly twice.

Sorghum variety SPV-2217 was sown at $45 \times 15 \mathrm{~cm}$ spacing using a seed rate of $7.5 \mathrm{~kg} / \mathrm{ha}$. Nitrogen and phosphorus @ $50: 25 \mathrm{~kg} \mathrm{~N}$ and $\mathrm{P}_{2} \mathrm{O}_{5} /$ ha in the form of urea and diammonium phosphate respectively were mixed with enriched FYM or vermicompost as per the treatments and applied at sowing. The other recommended pacakage of practice were followed to raise the crop. The total rainfall received during cropping period was $124.0 \mathrm{~mm}$ distributed in 9 rainy days which was
53.5 per cent deficit as against 66 years average rainfall. The rainfall of $41.6 \mathrm{~mm}$ was received on $29^{\text {th }}$ September an sowing was done. The rainfall during October and November month received a deficit rainfall to an extent of 70.8 and 80.9 per cent respectively as compared to average of 66 years. The furadon granules@12 kg/ha were applied to whorls of crop followed by cymbush spraying @ $10 \mathrm{ml}$ per 15 litre of water to control shoot fly and stem borer. The crop was sown on $29 / 09 / 2016$ and harvested on 10/02/2016. Plant samples of sorghum crop collected at harvest were used for estimation of nutrient content. The dried sample were ground and passed through 40 mesh sieve. The ground material was collected in butter paper bag and used for chemical analysis. Uptake of nitrogen, phosphorous, potassium, sulphur, iron and zinc (Tandon, 1998) [17] were recorded as per the standard procedure. The data collected on different parameters were subjected to statistical analysis as described by Panse and Sukhatme (1967) ${ }^{[11]}$ for better interpretation of results.

\section{Results and discussion Uptake of major nutrients}

Uptake of major nutrients by grain and fodder of rabi sorghum differed significantly due to soil application of different levels of fortified organics with iron sulphate and zinc sulphate (Table-1). Application of RDF + Enriched FYM 1 recorded significantly higher nitrogen uptake by both grain $(57.19 \mathrm{~kg} / \mathrm{ha})$ and fodder $(42.03 \mathrm{~kg} / \mathrm{ha})$ which was 73.0 and 78.6 per cent higher over control, 26.9 and 52.4 per cent higher over RDF (41.82 and $20.00 \mathrm{~kg} / \mathrm{ha}$ by grain and fodder respectively) and 18.6 and 42.7 per cent higher over RPP (46.58 and $24.08 \mathrm{~kg} / \mathrm{ha}$ by grain and fodder respectively) and was at par with rest of the enriched treatments (Table 1). There results corroborate the findings of Rathod et al. (2012) ${ }^{[15]}$. The beneficial effect of iron and zinc enriched organics in improving soil properties and enhancing nitrogen availability and its uptake has been reported by Latha et al. (2001) ${ }^{[9]}$. Phosphorus uptake both by grain and fodder was significantly higher with the soil application of RDF + Enriched FYM 1 (23.13 and $24.14 \mathrm{~kg} / \mathrm{ha}$ respectively) over control (2.42 and $3.12 \mathrm{~kg} / \mathrm{ha}$ respectively), RDF (11.17 and $14.19 \mathrm{~kg} / \mathrm{ha}$ respectively) and RPP (13.37 and $17.14 \mathrm{~kg} \mathrm{ha}^{-1}$ respectively) and it was at par with rest of the fortified treatments. Similarly, higher potassium uptake was recorded with the soil application of RDF + Enriched FYM 1 by grain $(20.08 \mathrm{~kg} / \mathrm{ha})$ and fodder $(44.96 \mathrm{~kg} / \mathrm{ha})$ as compared to control (4.89 and $6.41 \mathrm{~kg} / \mathrm{ha}$ by grain and fodder respectively), recommended dose of fertilizer $(7.55$ and $9.21 \mathrm{~kg} / \mathrm{ha}$ by grain and fodder respectively) and recommended package of practice (11.63 and $23.47 \mathrm{~kg} / \mathrm{ha}$ by grain and fodder respectively). Soil application of RDF + Enriched FYM 1 enhanced significantly the higher sulphur uptake by grain $(11.14 \mathrm{~kg} / \mathrm{ha})$ and fodder $(10.55 \mathrm{~kg} / \mathrm{ha})$ over control (4.50 and $4.28 \mathrm{~kg} / \mathrm{ha}$ by grain and fodder respectively), recommended dose of fertilizer (5.28 and $4.91 \mathrm{~kg} / \mathrm{ha}$ by grain and fodder respectively) and recommended package of practice $(8.82$ and $7.63 \mathrm{~kg} / \mathrm{ha}$ by grain and fodder respectively) (Table-1). The higher nitrogen uptake, phosphorus uptake, potassium uptake and sulphur uptake by grain and fodder may be attributed to higher grain and fodder yield and higher total dry matter production. These results were in agreement with the findings of Pawar et al. (2014) ${ }^{[12]}$ in kharif sorghum.

\section{Iron and zinc content and their uptake}

Iron and zinc content in the grain and fodder after harvest of the crop increased significantly due to soil application of 
different levels of enriched organics with iron and zinc as compared to control, recommended dose of fertilizer and recommended package of practice (Table-2). With an increased level of application of $\mathrm{FeSO}_{4}$ from 3.75 to $15 \mathrm{~kg} / \mathrm{ha}$ enriched with FYM and vermicompost, there was a linear increase in iron concentration in grain and fodder from 37.64 to $39.52 \mathrm{mg} / \mathrm{kg}$ and 40.69 to $42.34 \mathrm{mg} / \mathrm{kg}$ respectively. Similarly, with increased level of application of $\mathrm{ZnSO}_{4}$ from 3.75 to $15 \mathrm{~kg} / \mathrm{ha}$ enriched with FYM and vermicompost, the zinc concentration in grain and fodder increased from 27.11 to $28.44 \mathrm{mg} / \mathrm{kg}$ and 28.42 to $29.44 \mathrm{mg} / \mathrm{kg}$ respectively. Soil application of RDF + Enriched vermicompost 4 recorded significantly higher iron content both in grain $(39.52 \mathrm{mg} / \mathrm{kg}$ ) and fodder $(42.34 \mathrm{mg} / \mathrm{kg})$ which was 13.4 and 15.8 per cent higher over control (34.23 and $35.67 \mathrm{mg} / \mathrm{kg}$ in grain and fodder respectively), 12.6 and 13.8 per cent increase over recommended dose of fertilizer $(34.56$ and $36.49 \mathrm{mg} / \mathrm{kg}$ in grain and fodder respectively) and 9.4 and 9.4 per cent increase over recommended package of practice (35.79 and $38.36 \mathrm{mg} / \mathrm{kg}$ in grain and fodder respectively). Similarly, zinc content in grain and fodder was significantly higher with the soil application of RDF + Enriched vermicompost 4 (28.44 and $29.44 \mathrm{mg} / \mathrm{kg}$ respectively) which was 13.5 and 16.0 per cent increase over control (24.60 and $24.73 \mathrm{mg} / \mathrm{kg}$ in grain and fodder respectively), 12.2 and 14.5 per cent increase over recommended dose of fertilizer (24.97 and $25.17 \mathrm{mg} / \mathrm{kg}$ in grain and fodder respectively) and 7.4 and 5.6 per cent increase over recommended package of practice (26.33 and $27.78 \mathrm{mg} / \mathrm{kg}$ in grain and fodder respectively). These results were supported by the findings of by Mishra et al. (2015) ${ }^{[10]}$ in rabi sorghum. The higher iron and zinc content both in grain and fodder in RDF + Enriched vermicompost 4 might be due to the fact that enrichment of FYM and vermicompost with iron and zinc regulates supply of iron and zinc to the crop by slow releasing of the nutrients into soil solution. It also enhanced the mineralization process by converting unavailable nutrients in to available nutrients which might have taken up by the crop easily. Significantly higher iron uptake by grain and fodder in rabi sorghum was recorded with the soil application of RDF + Enriched FYM 1 (161.16 and $305.66 \mathrm{~g} / \mathrm{ha}$ respectively) which was 35.8 and 47.9 per cent higher over control, 19.8 and 23.6 per cent higher over recommended dose of fertilizer and 15.4 and 15.1 per cent higher over recommended package of practice, respectively (Table 2). Similarly higher zinc uptake by grain and fodder was noticed with the soil application of RDF + Enriched FYM 1 (116.27 and $213.21 \mathrm{~g} /$ ha respectively) which was 36.0 and 48.1 per cent higher over control, 19.7 and 24.4 per cent increase over recommended dose of fertilizer and 13.7 and 11.8 per cent increase over recommended package of practice.
The higher uptake of iron and zinc by grain and fodder was mainly attributed to higher dry matter production, higher grain and fodder yield. The higher uptake of iron and zinc by grain and fodder might be also due to the faster decomposition of organic and inorganic sources of nutrients and further, enrichment of nutrients with organics prevents them from leaching, fixation and other losses. This increases the available cationic micronutrient concentration in soil solution thereby increased the uptake of these micronutrients by grain and fodder. Similar findings were also reported by Adsul et al. (2014) ${ }^{[1]}$ in fodder sorghum.

\section{Available soil nutrients after harvest}

Soil application of RDF + Enriched FYM 1 recorded significantly lower available nitrogen in soil after harvest $(207.16 \mathrm{~kg} / \mathrm{ha})$ as compared to recommended package of practice $(235.38 \mathrm{~kg} / \mathrm{ha})$. While the lower available phosphorus was higher with the same treatment $(23.11 \mathrm{~kg} / \mathrm{ha})$ compared to RPP $(27.87 \mathrm{~kg} / \mathrm{ha})$. Recommended package of practice recorded significantly higher available nitrogen and phosphorus in soil after harvest which can be related to lower uptake of these nutrients by sorghum. Significantly lower available potassium and sulphur was recorded in the treatment containing RDF + Enriched FYM 1 (313.31 and $10.19 \mathrm{~kg} / \mathrm{ha})$ respectively over control, RDF and RPP (Table-3). Control recorded significantly higher available potassium and sulphur in soil after harvest of the crop due to the lowest uptake of potassium and sulphur by sorghum. The lower available nitrogen, phosphorus, potassium and sulphur in the soil after harvest may be attributed to enrichment of FYM and vermicompost with iron and zinc caused maximum utilization of nutrients and also due to its beneficial effect in mobilizing the native nutrients to increase their availability to crop (Latha et al., 2001) ${ }^{[9]}$.

Soil available iron and zinc after harvest of crop differed significantly due to application of different levels of iron and zinc enriched organics (Table 3). Soil application of RDF + Enriched FYM 4 recorded significantly higher available iron and zinc (4.70 and $0.626 \mathrm{mg} / \mathrm{kg}$ respectively) over control (4.06 and $0.520 \mathrm{mg} / \mathrm{kg}$ iron and zinc respectively) and RDF (4.04 and $0.517 \mathrm{mg} / \mathrm{kg}$ iron and zinc respectively). These results were in accordance with the findings of Kustigar (2016) ${ }^{[8]}$ in maize. This might be due to the fact that enriched organics enhanced the availability of nutrients in to the soil. It was also noticed that DTPA extractable iron and zinc in soil found to increase due to application of iron and zinc enriched organics into the soil.

Table 1: Nitrogen, phosphorous, potassium and sulphur uptake $\left(\mathrm{kg} \mathrm{ha}^{-1}\right)$ by grain and fodder of rabi sorghum as influenced by iron and zinc fortified with organics

\begin{tabular}{|c|c|c|c|c|c|c|c|c|c|}
\hline \multirow{2}{*}{\multicolumn{2}{|c|}{ Treatments }} & \multicolumn{2}{|c|}{ Nitrogen uptake } & \multicolumn{2}{|c|}{ Phosphorous uptake } & \multicolumn{2}{|c|}{ Potassium uptake } & \multicolumn{2}{|c|}{ Sulphur uptake } \\
\hline & & Grain & Fodder & Grain & Fodder & Grain & Fodder & Grain & Fodder \\
\hline $\mathrm{T}_{1}-$ & Control (No nutrients) & 15.46 & 8.99 & 2.42 & 3.12 & 4.89 & 6.41 & 4.50 & 4.28 \\
\hline $\mathrm{T}_{2}-$ & Recommended dose of fertilizer (RDF) & 41.82 & 20.00 & 11.77 & 14.19 & 7.55 & 9.21 & 5.28 & 4.91 \\
\hline $\mathrm{T}_{3}-$ & Recommended package of practice (RPP) & 46.58 & 24.08 & 13.37 & 17.14 & 11.63 & 23.47 & 8.82 & 7.63 \\
\hline $\mathrm{T}_{4}-$ & RDF + Enriched FYM 1 & 57.19 & 42.03 & 23.13 & 24.14 & 20.08 & 44.96 & 11.14 & 10.55 \\
\hline $\mathrm{T}_{5}-$ & RDF + Enriched FYM 2 & 54.55 & 37.98 & 21.81 & 21.90 & 16.43 & 39.66 & 10.69 & 10.08 \\
\hline $\mathrm{T}_{6}-$ & RDF + Enriched FYM 3 & 50.92 & 31.34 & 18.63 & 19.64 & 13.35 & 30.31 & 9.47 & 8.94 \\
\hline $\mathrm{T}_{7}-$ & RDF + Enriched FYM 4 & 51.25 & 31.01 & 18.21 & 18.78 & 14.58 & 31.57 & 9.49 & 9.57 \\
\hline $\mathrm{T}_{8}-$ & RDF + Enriched vermicompost 1 & 55.88 & 38.67 & 22.12 & 22.27 & 18.47 & 42.53 & 10.74 & 10.25 \\
\hline $\mathrm{T}_{9}-$ & RDF + Enriched vermicompost 2 & 51.06 & 28.62 & 19.84 & 20.14 & 14.11 & 31.42 & 9.28 & 8.81 \\
\hline $\mathrm{T}_{10}-$ & RDF + Enriched vermicompost 3 & 52.94 & 35.04 & 21.16 & 21.51 & 15.75 & 38.13 & 10.31 & 9.72 \\
\hline $\mathrm{T}_{11}-$ & RDF + Enriched vermicompost 4 & 52.20 & 32.31 & 20.09 & 20.67 & 15.05 & 33.64 & 10.12 & 9.14 \\
\hline & S.Em. + & 1.22 & 1.10 & 0.44 & 0.43 & 0.58 & 0.71 & 0.22 & 0.28 \\
\hline & C.D. $(\mathrm{P}=0.05)$ & 3.59 & 3.25 & 1.31 & 1.26 & 1.72 & 2.10 & 0.64 & 0.83 \\
\hline
\end{tabular}


Table 2: Iron and zinc content and their uptake by grain and fodder of rabi sorghum as influenced by iron and zinc fortified with organics

\begin{tabular}{|c|c|c|c|c|c|c|c|c|c|}
\hline & \multirow[t]{2}{*}{ Treatments } & \multicolumn{2}{|c|}{$\begin{array}{c}\text { Iron content } \\
\left(\mathrm{mg} \mathrm{kg}^{-1}\right)\end{array}$} & \multicolumn{2}{|c|}{$\begin{array}{c}\text { Zinc content } \\
\left(\mathrm{mg} \mathrm{kg}^{-1}\right)\end{array}$} & \multicolumn{2}{|c|}{$\begin{array}{c}\text { Iron uptake } \\
\left(\mathrm{g} \mathrm{ha}^{-1}\right)\end{array}$} & \multicolumn{2}{|c|}{$\begin{array}{c}\text { Zinc uptake } \\
\left(\mathrm{g} \mathrm{ha}^{-1}\right)\end{array}$} \\
\hline & & Grain & Fodder & Grain & Fodder & Grain & Fodder & Grain & Fodder \\
\hline $\mathrm{T}_{1}-$ & Control (No nutrients) & 34.23 & 35.67 & 24.60 & 24.73 & 103.46 & 159.29 & 74.46 & 110.62 \\
\hline $\mathrm{T}_{2}-$ & Recommended dose of fertilizer (RDF) & 34.56 & 36.49 & 24.97 & 25.17 & 129.21 & 233.56 & 93.39 & 161.19 \\
\hline $\mathrm{T}_{3}-$ & Recommended package of practice (RPP) & 35.79 & 38.36 & 26.33 & 27.78 & 136.35 & 259.42 & 100.29 & 188.04 \\
\hline $\mathrm{T}_{4}-$ & RDF + Enriched FYM 1 & 37.64 & 40.69 & 27.11 & 28.42 & 161.16 & 305.66 & 116.27 & 213.21 \\
\hline $\mathrm{T}_{5}-$ & RDF + Enriched FYM 2 & 38.02 & 41.03 & 27.47 & 28.78 & 155.56 & 301.83 & 112.30 & 211.34 \\
\hline $\mathrm{T}_{6}-$ & RDF + Enriched FYM 3 & 38.71 & 41.54 & 27.82 & 29.06 & 152.70 & 289.76 & 109.63 & 202.75 \\
\hline $\mathrm{T}_{7}-$ & RDF + Enriched FYM 4 & 39.32 & 42.14 & 28.21 & 29.30 & 155.27 & 286.54 & 111.52 & 199.65 \\
\hline $\mathrm{T}_{8}-$ & RDF + Enriched vermicompost 1 & 37.94 & 40.93 & 27.54 & 28.49 & 155.24 & 291.41 & 112.70 & 202.57 \\
\hline $\mathrm{T}_{9}-$ & RDF + Enriched vermicompost 2 & 38.30 & 41.25 & 27.92 & 28.91 & 151.67 & 283.62 & 110.55 & 198.90 \\
\hline $\mathrm{T}_{10-}$ & RDF + Enriched vermicompost 3 & 38.84 & 41.68 & 28.06 & 29.13 & 157.30 & 295.61 & 113.81 & 206.40 \\
\hline $\mathrm{T}_{11-}$ & RDF + Enriched vermicompost 4 & 39.52 & 42.34 & 28.44 & 29.44 & 159.50 & 303.53 & 114.92 & 210.80 \\
\hline & S.Em.+ & 0.73 & 1.05 & 0.47 & 0.35 & 5.75 & 13.25 & 4.13 & 7.58 \\
\hline & C.D. $(\mathrm{P}=0.05)$ & 2.16 & 3.11 & 1.37 & 1.04 & 16.96 & 39.09 & 12.17 & 22.36 \\
\hline
\end{tabular}

Table 3: Available nitrogen, phosphorous, potassium, Sulphur, iron and zinc in soil after harvest of rabi sorghum as influenced by iron and zinc fortified with organics

\begin{tabular}{|c|c|c|c|c|c|c|c|}
\hline \multirow{2}{*}{\multicolumn{2}{|c|}{ Treatments }} & Nitrogen & Phosphorous & Potassium & Sulphur & Iron & Zinc \\
\hline & & \multicolumn{4}{|c|}{$\left(\mathrm{kg} \mathrm{ha}^{-1}\right)$} & \multicolumn{2}{|c|}{$\left(\mathrm{mg} \mathrm{kg}^{-1}\right)$} \\
\hline \multicolumn{2}{|r|}{ Initial soil nutrient status } & 245 & 22.64 & 357.36 & 19.80 & 4.24 & 0.54 \\
\hline $\mathrm{T}_{1}-$ & Control (No nutrients) & 217.60 & 21.06 & 349.11 & 15.82 & 4.06 & 0.52 \\
\hline $\mathrm{T}_{2}-$ & Recommended dose of fertilizer (RDF) & 228.59 & 25.07 & 345.89 & 15.69 & 4.04 & 0.52 \\
\hline $\mathrm{T}_{3}-$ & Recommended package of practice (RPP) & 235.38 & 27.87 & 340.57 & 15.06 & 4.66 & 0.62 \\
\hline $\mathrm{T}_{4}-$ & RDF + Enriched FYM 1 & 207.16 & 23.11 & 313.31 & 10.19 & 4.58 & 0.61 \\
\hline $\mathrm{T}_{5}-$ & RDF + Enriched FYM 2 & 214.76 & 24.88 & 320.89 & 11.64 & 4.61 & 0.63 \\
\hline $\mathrm{T}_{6}-$ & RDF + Enriched FYM 3 & 224.10 & 26.63 & 335.18 & 13.67 & 4.69 & 0.63 \\
\hline $\mathrm{T}_{7}-$ & RDF + Enriched FYM 4 & 225.07 & 27.63 & 332.64 & 13.94 & 4.70 & 0.63 \\
\hline $\mathrm{T}_{8}-$ & RDF + Enriched vermicompost 1 & 212.12 & 25.26 & 318.53 & 11.37 & 4.59 & 0.61 \\
\hline $\mathrm{T}_{9}-$ & RDF + Enriched vermicompost 2 & 229.69 & 26.12 & 333.19 & 13.49 & 4.67 & 0.62 \\
\hline $\mathrm{T}_{10}-$ & RDF + Enriched vermicompost 3 & 218.74 & 26.69 & 323.90 & 12.87 & 4.63 & 0.62 \\
\hline $\mathrm{T}_{11-}$ & RDF + Enriched vermicompost 4 & 221.73 & 26.33 & 329.26 & 12.23 & 4.64 & 0.62 \\
\hline \multicolumn{2}{|r|}{ S.Em. +} & 2.83 & 0.37 & 3.01 & 0.45 & 0.13 & 0.02 \\
\hline \multicolumn{2}{|r|}{ C.D. $(\mathrm{P}=0.05)$} & 8.36 & 1.10 & 8.87 & 1.32 & 0.38 & 0.06 \\
\hline
\end{tabular}

\section{Conclusion}

Based on the results, it may be concluded that application of fortified form of either FYM or vermicompost with iron sulphate and zinc sulphate to rabi sorghum enhanced the iron and zinc content in grain and fodder along with nutrient uptake. Thus, soil application of RDF with Enriched FYM 1 (50 kg FYM/ha + $3.75 \mathrm{~kg} \mathrm{ZnSO}_{4} / \mathrm{ha}$ ) to rabi sorghum found optimum as compared to direct application of iron and zinc without fortification.

\section{References}

1. Adsul PB, Pawar A, Gaikwad G, Puri A, Shaikh MSS. Uptake of N, P, K and yield of kharif sorghum as influenced by soil and foliar application of micronutrients. Bioinfolet. 2014; 11(2C):578-582.

2. Black RE, Lindsay HA, Bhutta ZA, Caulfield LE, De Onnis M, Ezzati M et al. Maternal and child under nutrition: global and regional exposures and health consequences. Lancet. 2008; 371:243-60.

3. Cababallero B. Global patterns of child health the role of nutrition. Ann. Nutrtion. Metab. 2002; 46: 3-7.

4. Cakmak I. Enrichment of cereal grains with zinc, agronomic or genetic bio fortification. Plant Soil. 2008; 302: 1-17.

5. Chaney RL, Coulombe BA, Bell PR, Angle JS. Detailed method to screen dicot cultivators for resistance to $\mathrm{Fe}$ chlorosis using FeDTPA and bicarbonate in nutrient solutions. J. Plant. Nutr. 1992; 15:2063-2083.
6. Kumar A, Sen A, Dev CM. Effect of iron, zinc and manganese levels on yield and yield attributing characters of rice. Bioinfolet. 2013; 10(3B):924-929.

7. Kumssa DB, Joy EJM, Ander JEL, Watts MJ, Young SD, Walker S et al. Dietary calcium and zinc deficiency risks are decreasing but remain prevalent. Sci. Rep. 2015; 5:10974.

8. Kustigar N. Agronomic biofortification of zinc and iron micronutrients in maize. M Sc thesis, UAS, Dharwad, 2016.

9. Latha MR, Savithri P, Indirani R, Kamaraj S. Influence of zinc enriched organic manures on the availability of micronutrients in soil. Madras Agric. J. 2001; 88: 165167.

10. Mishra JS, Hariprasanna K, Rao SS, Patil JV. Biofortification of post-rainy sorghum (Sorghum bicolor) with zinc and iron through fertilization strategy. Indian J. Agric. Sci. 2015; 85(5):721-724.

11. Panse VG, Sukhatme PV. Statistical Methods for Agricultural Workers, ICAR, Publication New Delhi, 1967, 359.

12. Pawar A, Adsul PB, Gaikwad G, Puri A, Shaikh MSS. Influence of zinc and iron application on kharif sorghum. Bioinfolet. 2014; 11(2):572-574.

13. Pfeiffer WH, McClafferty B. Harvest Plus: Breeding crops for better nutrition. Crop Sci. 2007; 47: S88-S105.

14. Rao P, Birthal BS, Reddy BVS, Rai KN, Ramesh S. 2006. Diagnostics of sorghum and pearl millet grains 
based nutrition in India. Intl. Sorghum and Millets Newsletter. 2006; 47:93-96.

15. Rathod DD, Meena MC, Patel KP. Effect of different Znenriched organics on yields and micronutrient uptake under wheat-maize cropping sequence in semi- arid region of Gujarat. Indian J Dryland Agric. Res. Dev. 2012; 27 (1):37- 42.

16. Singh MV. Evaluation of current micronutrient stocks in different agro-ecological zones of India for sustainable crops production. Fert. News. 2001; 42:25-42.

17. Tandon HLS. Methods of analysis of soils, plants, water and fertilizers. Fertilizer Development and Consultant Organization, 1998, 43.

18. Welch RM, Graham RD. Breeding for micronutrients in staple food crops from a human nutrition perspective. J. Exp. Bot. 2004; 55:353-364. 